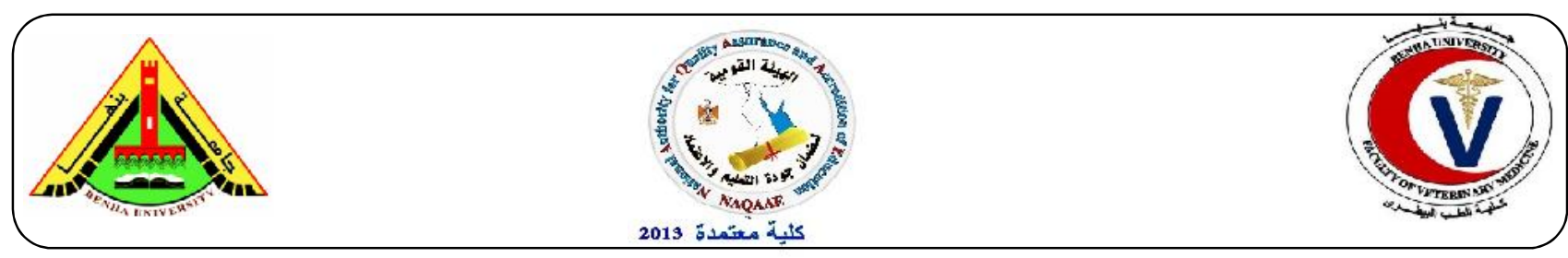

\title{
Phenotypic and Genotypic Characterization of Some Bacterial Isolates (Escherichia Coli, Klebsiella Oxytoca) From Chickens
}

\author{
1 Abd El-Tawab A.A., ${ }^{2}$ Selim A.O. and ${ }^{1}$ Soliman A.M.. \\ ${ }^{1}$ Bacteriology, Immunology and Mycology Dep., Fac. Vet. Med. Benha Univ. \\ ${ }^{2}$ Animal Health Research, Benha branch .
}

\begin{abstract}
A B STR A C T
The present study was performed on a total of 104 recently dead chickens from Gharbia Governorate that inspected for Enterobacteriaceae from internal organs after clinical and postmortem examination. The results revealed that 95 samples were positive, Escherichia coli (53), where Salmonella.spp. (31), Citrobacter freundii (14), Enterobacter cloacae (6), Klebsiella oxytoca (5), Proteus vulgaris (4) , Acinetobacter lowoffii, Edwardsiella tarda respectively, and Enterobacter gergoviae, Enterobacter pantoe (2) respectively. Amikacin and gentamicin were the highest efficiency antimicrobial agents used in vitro with variation in sensitivity to others except Proteus vulgaris was resist to all. Seven E.coli isolates were serotyped and identified as $\mathrm{O}_{1}, \mathrm{O}_{6}$, $\mathrm{O}_{125}$ and $\mathrm{O}_{146}$. PCR results for E.coli showed that $t s p \mathrm{E} 4 \mathrm{c} 2$ and $y j a \mathrm{~A}$ pathotypic genes( at 152 bp and $211 \mathrm{bp}$ ) were detected in all, but only $\mathrm{O}_{125}$ and $\mathrm{O}_{146}$ have chuA gene ( at $279 \mathrm{bp}$ ). While hlyA (at $450 \mathrm{bp}$ ) was detected in $\mathrm{O}_{6}$, eaeA (at 248bp) and stx1(at $614 \mathrm{bp}$ ) gene was detected in 1 strain of $\left(\mathrm{O}_{125}\right)$, iss gene (at $323 \mathrm{bp}$ ) was detected in another isolate of $\mathrm{O}_{125}$ and stx2 (at $779 \mathrm{bp}$ ) was absent in all. All that indicate that $E$. coli strains isolated were extra-intestinal pathogenic strains. PCR results for 5 studied $K$. oxytoca strains showed that all of them leak iro $\mathrm{N}$,but all have pehX gene.
\end{abstract}

Key words: Escherichia coli, Klebsiella oxytoca, chickens, PCR .

(http://www.bvmj.bu.edu.eg)

(BVMJ-35(2): 284-302, 2018)

\section{INTRODUCTION}

Poultry industry plays an important role in the national income .They are domesticated birds raised for their meat, eggs and their edible offals. Poultry is the second most widely eaten type of meat in the world especially chickens. Bacteria are responsible for important group of naturally occurring diseases of chickens. These diseases cause substantial morbidity and mortality which mostly involve the respiratory and digestive systems. Although conferring many healthassociated benefits, gastrointestinal tract bacteria shows some drawbacks rather than pathogenesis. They compete with the host for nutrients within the GIT and may secrete toxic and anti-nutritional compounds that induce a continuous inflammatory response in the GIT and stimulate fast turnover of epithelial cells at the expense of bird performance (Yegani and Korver 2008) 
.Enterobacteriaceae are gram negative bacteria which their members are widely distributed throughout the environment in soil, water, on plants as well as in the intestines of animals. However, Salmonella typhi, that causes typhoid fever in man and is found only in humans. Enterobacteriaceae can cause disease by attacking their host in a number of ways. The most important factors are motility, colonization factors, endotoxin and enterotoxin ( Markey et.al., (2013). The family Enterobacteriaceae consists of many strains that colonize the small and large intestine, and includes members of commensal microbiota as well as pathogens. Several pathogenic Enterobacteriaceae, specially Escherichia coli strains, cause diarrhoea, urinary tract infections, mastitis, arthritis and meningitis in both humans and animals (Fairbrother et al., 2005 and Nagy and Fekete 2005). Salmonella spp. cause bacillary white diarrhea, enteritis and septicaemia in chicks and fowl typhoid in all ages. Fimbrial gene clusters isolated from Salmonella genomes may be associated with tissue tropism due to host specificity or receptor specificity (Kisiela et al., 2012 and Yue et al., 2012). Enterobacteriaceae can be divided into three groups based on their pathogenicity into : Major pathogens of animals such as Salmonella species, Escherichia coli and 3 of the Yersinia species and the other side is opportunistic pathogens that are occasionally cause infections as Proteus, Klebsiella, Enterobacter, Serratia, Edwardsiella, Citrobacter, Morganella and Shigella and organisms of uncertain significance for animals (Markey et.al., 2013).

Colibacillosis is the most frequently reported live poultry diseases or at processing. Healthy and sick broilers, layers, and breeders showed the incidence of avian pathogenic E.coli infection to be $17.7 \%, 38.6 \%$, and $26.9 \%$ with high percent of multi-drug resistance.
Salmonellosis can transmitted by vertical, horizontal or mechanical transmission which cause variation in mortality from PD , maximize during the second week after hatching, with a rapid decline between $3-4$ week of age and mortality from FT ranging from $10-93 \%$. It's mortality rate is often higher than morbidity rate. So the aim of the work was studing the phenotypic and the genotypic characters of some bacteria isolated from chickens.

\section{MATERIALS AND METHODS}

\subsection{Sample collection}

A total of 104, recently dead chickens , from different farms at Gharbia Governorate for bacteriological examination. The examined chickens were of different ages. Each examined organ was taken alone in sterile packet in ice bag with minimum of delay for bacteriological examination from liver, gizzard, heart, lung and spleen from all ages and both sexes.

\subsection{Bacteriological examination}

A small piece of the organ was inoculated in the Macconkey broth and then incubated at $37^{\circ} \mathrm{C}$ for 24 hours. Loopfuls from Macconkey broth was inoculated on Macconkey agar then nutrient agar incubated at $37^{\circ} \mathrm{C}$ for $24-48$ hours. Cultivation on selective media as XLD, Brilliant green, EMB for Entrobacteriaceae. Suspected colonies were picked up and sub cultured on brain heart broth $+50 \%$ glycerol and incubated at $37^{\circ} \mathrm{C}$ for 24 hours, then kept in freezer for further studies ( Markey et.al., 2013).

\subsection{In-Vitro anti-microbial sensitivity test:}

Subculture from the isolated strains were prepared and subjected to the sensitivity test against different antimicrobial discs ( Markey et.al., 2013) ( table,3). 


\subsection{Biofilm of E. coli isolated:}

A loopful of E. coli was inoculated in 10 $\mathrm{mL}$ of trypticase soy broth with $1 \%$ glucose in test tubes. The tubes were incubated at $37^{\circ} \mathrm{C}$ for $24 \mathrm{hr}$. After incubation, tubes were decanted and washed with phosphate buffer saline $(\mathrm{pH} 7.3)$ and dried. Tubes were then stained with crystal violet $(0.1 \%)$. Excess stain was washed with deionized water. Tubes were dried in inverted position. The scoring for tube method was done according to the results of the control strains. Biofilm formation was considered positive when a visible film lined the wall and the bottom of the tube.

\subsection{Serological identification of E. coli and} K. oxytoca isolates

E.coli isolated were identified serologically using E. coli polyvalent and monovalent $\mathrm{O}$ antisera by slide agglutination technique. The tested strains were picked up from an 24 hours old colony on nutrient agar was emulsified with a loop in the drop of the

\section{RESULTS}

The postmortem lesions of diseased chickens included fibrinous pericarditis, perihepatitis, congestion with petechial hemorrhages in internal organs as liver, lung, spleen, kidneys, heart and intestine. The results of isolation (Table,1-2) showed 95/104 (91.35\%) were positive for Enterobacteriacae isolation, where 10 different bacterial isolates. E. coli isolated from 53 samples, $K$. oxytoca isolated from 5 samples, S.spp isolated from 31samples, Citrobacter freundii isolated from 14 samples, Enterobacter cloacae isolated from 6 samples, Enterobacter gergoviae isolated from 2 samples, Enterobacter pantoe isolated from 2 samples, Acinetobacter lowoffii isolated from 4 samples, Proteus vulgaris isolated from 4 physiological saline on the slide and mixed thoroughly with a drop of antiserum for one minutes at El dokki institute according to Markey et.al., (2013).

\subsection{Virulence genes of E.coli detection by PCR}

PCR was applied by using eight sets of primers for detection of 8 pathotyping and virulence genes that may play a role in virulence of E.coli (table,7). These genes were hemeutilization protein A gene (chuA), Specific DNA fragment ( $t s p \mathrm{E} 4 \mathrm{c} 2)$ and Inner membrane protein (yjaA), intimin gene (eae A), increased serum survival gene (iss), haemolysin (hlyA), shiga toxin 1 gene (stx 1 ) and shiga toxin 2 gene (stx2). Tested genes used for K. oxytoca were (pehX) polygalacturonase gene and iroN .It was applied on 7 random isolates of E.coli and 2 isolates of K.oxytoca following QIAamp® DNA Mini Kit instructions (Catalogue no. 51304);Emerald Amp GT PCR mastermix (Takara) Code No.RR310A and agarose gel electrophoreses (Sambrook et al.,1989).

samples and Edwardsiella tarda isolated from 4 samples.

The in- vitro sensitivity tests showed that the isolated all E.coli strains, Salmonellae species, klebsiella oxytoca, Edwadsiella tarda and Enterobacter spp. showed high sensitivity to amikacin, gentamicin, variation in sensitivity to apramycin, spiramycin , trimethoprime and resist to neomycin, kanamycin,

spectinomycin, lincomycin, oxytetracycline. Citrobacter freundii revealed high sensitivity to amikacin , gentamicin , neomycin , apramycin and resistant to lincomycin , kanamycin , oxytetracycline, spiramycin, trimethoprime, spectinomycin. Acinetobacter lowoffii isolates showed high sensitivity to apramycin, moderate sensitivity to amikacin, gentamicin, trimethoprime, spectinomycin, 
spiramycin and resistant to oxytetracycline. Proteus vulgaris isolates showed high resistance to all antimicrobial agents used.

The result of E.coli biofilm (table,4) was $46.5 \%$ strong, $23.3 \%$ weak and $30.2 \%$ negative for biofilm formation. Seven E.coli strains were serotyped (Table,4) and four serovars were identified $\mathrm{O}_{1}, \mathrm{O}_{6}, \mathrm{O}_{125}$ and $\mathrm{O}_{146}(28.57 \%-14.29 \%-28.57 \%-28.57 \%$ respectively).

PCR results of pathotyping and virulence genes detection to E.coli serovares (table,7,8) showed that $t s p \mathrm{E} 4 \mathrm{c} 2$ and $y j a \mathrm{~A}$ pathotyping genes were detected in all ,but only 4 strains have chuA gene. While hlyA, eaeA and stxlgenes was detected in 1 strain of $\mathrm{O}_{125}$, iss gene was detected in another isolate of $\mathrm{O}_{125}$ and st 22 was absent in all studied strains.

Four samples showed positive amplification of chuA gene at 279 bp (fig.1).
All samples showed positive amplification of yjaA gene at 211 bp (fig.2). All samples showed positive amplification of $t s p \mathrm{E} 4 \mathrm{c} 2$ gene at 152 bp (fig.3). All samples showed negative amplification of stx2 gene at $779 \mathrm{bp}$ and one sample showed positive amplification of stx 1 gene at $614 \mathrm{bp}$ (fig. 4). One sample showed positive amplification of eaeA gene at 248 bp (fig. 5). One sample showed positive amplification of hly gene at $450 \mathrm{bp}$ and one sample showed positive amplification of iss gene at $323 \mathrm{bp}$ (fig. 6). PCR results of virulence genes detection to K.oxytoca (table,9) showed that 3 of tested isolates had no iroN gene and other 2 samples were not done while all of them had pehX gene. All samples showed positive amplification of pehX gene at 343 bp (fig. 7) and all showed negative amplification of iro $\mathrm{N}$ gene at $847 \mathrm{bp}$ (fig. 8). 
Table (1) The isolated bacteria from diseased chickens (Pure infection) $n=104$ :

\begin{tabular}{lccc}
\hline \multicolumn{1}{r}{ Isolates } & No. & $\%^{*}$ & $\%^{* *}$ \\
\hline Acinetobacter lowoffii & 2 & 1.9 & 2.1 \\
Citrobacter freundii & 10 & 9.6 & 10.53 \\
Enterobacter cloacae & 2 & 1.9 & 2.1 \\
E. coli & 42 & 40.38 & 44.2 \\
Klebsiella oxytoca & 2 & 1.9 & 2.1 \\
Salmonella spp. & 8 & 7.6 & 8.42 \\
Total & 66 & 63.5 & 69.45 \\
\hline
\end{tabular}

$*=\%$ according to total number of samples. $\mathrm{n}=104$.

$* *=\%$ according to positive samples. $\mathrm{n}=95$.

Table (2) The isolated bacteria from diseased chickens ( mixed infection) $n=104$ :

\begin{tabular}{|c|c|c|c|}
\hline Isolates & No. & $\% *$ & $\% * *$ \\
\hline Acinetobacter lowoffii + Salmonella spp. & 2 & 1.9 & 2.1 \\
\hline Citrobacter freundii + Proteus vulgaris & 2 & 1.9 & 2.1 \\
\hline Enterobacter cloacae + Salmonella spp. & 4 & 3.8 & 4.21 \\
\hline Enterobacter pantoe + Salmonella spp. & 2 & 1.9 & 2.1 \\
\hline E. coli + Enterobacter gergoviae & 2 & 1.9 & 2.1 \\
\hline E. coli + Klebsiella oxytoca & 2 & 1.9 & 2.1 \\
\hline E. coli + Salmonella spp. & 6 & 5.7 & 6.32 \\
\hline E. coli + Salmonella spp. + Klebsiella oxytoca & 1 & 0.96 & 1.1 \\
\hline Proteus vulgaris + Salmonella spp. & 2 & 1.9 & 2.1 \\
\hline Salmonella spp. + Citrobacter freundii & 2 & 1.9 & 2.1 \\
\hline Salmonella spp. + Edwardsiella tarda & 4 & 3.8 & 4.21 \\
\hline Total & 29 & 27.9 & 30.55 \\
\hline
\end{tabular}

$*=\%$ according to total number of samples. $\mathrm{n}=104$.

$* *=\%$ according to positive samples. $\mathrm{n}=95$. 
Table (3) Interpretation of zones inhibition for antimicrobial susceptibility (Modified from CLSI (2017)

\begin{tabular}{|c|c|c|c|c|c|}
\hline \multirow{2}{*}{ Antimicrobial agents } & \multirow{2}{*}{$\begin{array}{l}\text { Abbre- } \\
\text { viation }\end{array}$} & \multirow{2}{*}{$\begin{array}{l}\text { Disc content } \\
\text { in ug }\end{array}$} & \multicolumn{3}{|c|}{ Diameter of inhibition to nearest $\mathrm{mm}$. } \\
\hline & & & Resistant & intermediate & Susceptible \\
\hline Amikacin & Ak. & $30 \mathrm{ug}$ & $\leq 14$ & $15-16$ & $\geq 17$ \\
\hline Apramycin & Apr. & $15 \mathrm{ug}$ & $\leq 12$ & $12-14$ & $>14$ \\
\hline Gentamicin & $\mathrm{CN}$. & $120 \mathrm{ug}$ & $\leq 12$ & $13-14$ & $\geq 15$ \\
\hline Kanamycin & $\mathrm{K}$. & $30 \mathrm{ug}$ & $\leq 3$ & $14-17$ & $\geq 18$ \\
\hline Lincomycin & MY. & $10 \mathrm{ug}$ & $\leq 1$ & $12-14$ & $>14$ \\
\hline Neomycin & N. & $30 \mathrm{ug}$ & $\leq 17$ & $18-20$ & $\geq 21$ \\
\hline Oxytetracycline & OT. & $30 \mathrm{ug}$ & $\leq 14$ & $15-18$ & $\geq 19$ \\
\hline Spectinomycin & SH. & $100 \mathrm{ug}$ & $\leq 10$ & $14-17$ & $\geq 14$ \\
\hline Spiramycin & SP. & $100 \mathrm{ug}$ & $\leq 14$ & $15-18$ & $\geq 19$ \\
\hline $\begin{array}{l}\text { Trimethoprim }+ \\
\text { sulfamethoxazole }\end{array}$ & SXT. & $25 \mathrm{ug}$ & $\leq 10$ & $11-15$ & $\geq 16$ \\
\hline
\end{tabular}

Table (4) Biofilm results of $E$. coli isolated from diseased chickens (n = 43)

\begin{tabular}{ccccccc}
\hline Total & \multicolumn{2}{c}{ Strong } & \multicolumn{2}{c}{ Weak } & \multicolumn{2}{c}{ Negative } \\
\hline & No. & $\%$ & No. & $\%$ & No. & $\%$ \\
43 & 20 & 46.5 & 10 & 23.3 & 13 & 30.2 \\
\hline
\end{tabular}

Table (5) Distribution of E. coli serovars isolated from diseased chickens

\begin{tabular}{ccccccccc}
\hline Total & \multicolumn{2}{c}{$\mathrm{O}_{1}$} & \multicolumn{2}{c}{$\mathrm{O}_{6}$} & \multicolumn{2}{c}{$\mathrm{O}_{125}$} & \multicolumn{2}{c}{$\mathrm{O}_{146}$} \\
\hline & No. & $\%$ & No. & $\%$ & No. & $\%$ & No. & $\%$ \\
7 & 2 & 28.57 & 1 & 14.29 & 2 & 28.57 & 2 & 28.57 \\
\hline
\end{tabular}


Table (6): Oligonucleotide primers sequences for detection of 3 phylogenetic genes of E. coli and 7 virulence associated genes in E. coli, Klebsiella oxytoca isolates with PCR:

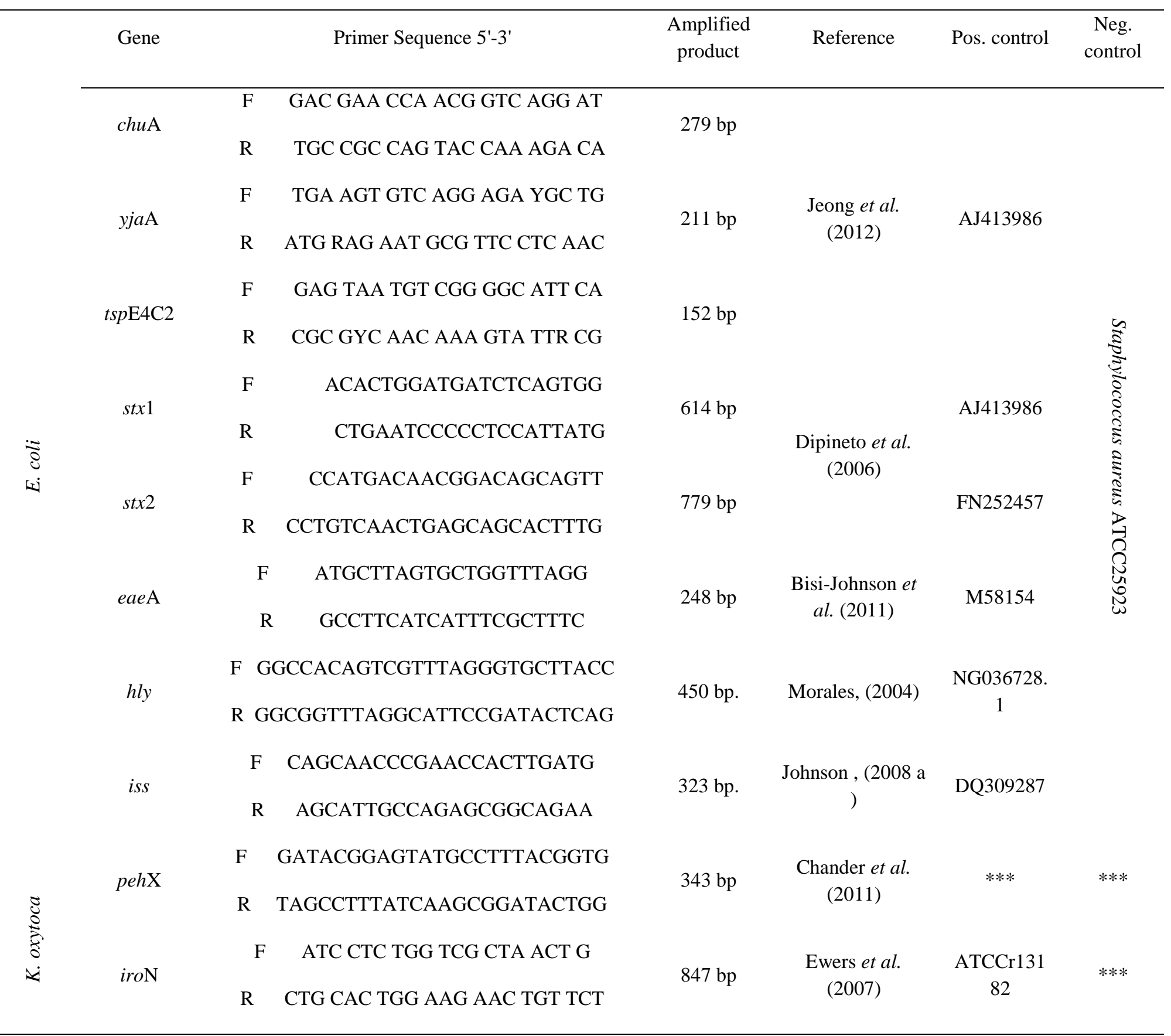


Table (7) : Phylogenetic group determination to E.coli strains isolated

\begin{tabular}{|c|c|c|c|c|c|c|}
\hline \multirow{2}{*}{$\begin{array}{c}\text { Sample } \\
\text { no. }\end{array}$} & \multirow{2}{*}{$\begin{array}{l}\text { E. coli } \\
\text { strains }\end{array}$} & \multicolumn{3}{|c|}{ Results } & \multirow[t]{2}{*}{ Grouping } & \multirow{2}{*}{$\begin{array}{c}\text { Sub- } \\
\text { grouping }\end{array}$} \\
\hline & & chuA & $y j a \mathrm{~A}$ & $t s p \mathrm{E} 4 \mathrm{c} 2$ & & \\
\hline 1 & $\mathrm{O}_{6}$ & - & + & + & Un-typeable & $* *$ \\
\hline 2 & $\mathrm{O}_{125}$ & + & + & + & $\mathrm{B}_{2}$ & $\mathrm{~B}_{23}$ \\
\hline 3 & $\mathrm{O}_{125}$ & + & + & + & $\mathrm{B}_{2}$ & $\mathrm{~B}_{23}$ \\
\hline 4 & $\mathrm{O}_{1}$ & - & + & + & Un-typeable & $* *$ \\
\hline 5 & $\mathrm{O}_{1}$ & - & + & + & Un-typeable & $* *$ \\
\hline 6 & $\mathrm{O}_{146}$ & + & + & + & $\mathrm{B}_{2}$ & $\mathrm{~B}_{23}$ \\
\hline 7 & $\mathrm{O}_{146}$ & + & + & + & $\mathrm{B}_{2}$ & $\mathrm{~B}_{23}$ \\
\hline
\end{tabular}

(Table 8): Results of virulence genes of E.coli strains isolated

\begin{tabular}{ccccccc}
\hline Sample no. & $\begin{array}{c}\text { E. coli } \\
\text { strains }\end{array}$ & stx 1 & stx2 & eaeA & iss & hly \\
\hline 1 & $\mathrm{O}_{6}$ & - & - & - & - & + \\
2 & $\mathrm{O}_{125}$ & - & - & - & + & - \\
3 & $\mathrm{O}_{125}$ & + & - & + & - & - \\
4 & $\mathrm{O}_{1}$ & - & - & - & - & - \\
5 & $\mathrm{O}_{1}$ & - & - & - & - & - \\
6 & $\mathrm{O}_{146}$ & - & - & - & - & - \\
7 & $\mathrm{O}_{146}$ & - & - & - & - & - \\
\hline
\end{tabular}

Table (9) PCR results of $K$. oxytoca isolated from diseased chickens :

\begin{tabular}{crr}
\hline Klebsiella sample & pehX & $\begin{array}{r}\text { Results } \\
\text { iro N }\end{array}$ \\
\hline 1 & + & - \\
2 & + & - \\
3 & + & - \\
4 & + & $\mathrm{ND}$ \\
5 & + & $\mathrm{ND}$ \\
\hline
\end{tabular}

$\mathrm{ND}=$ none done 
chuA

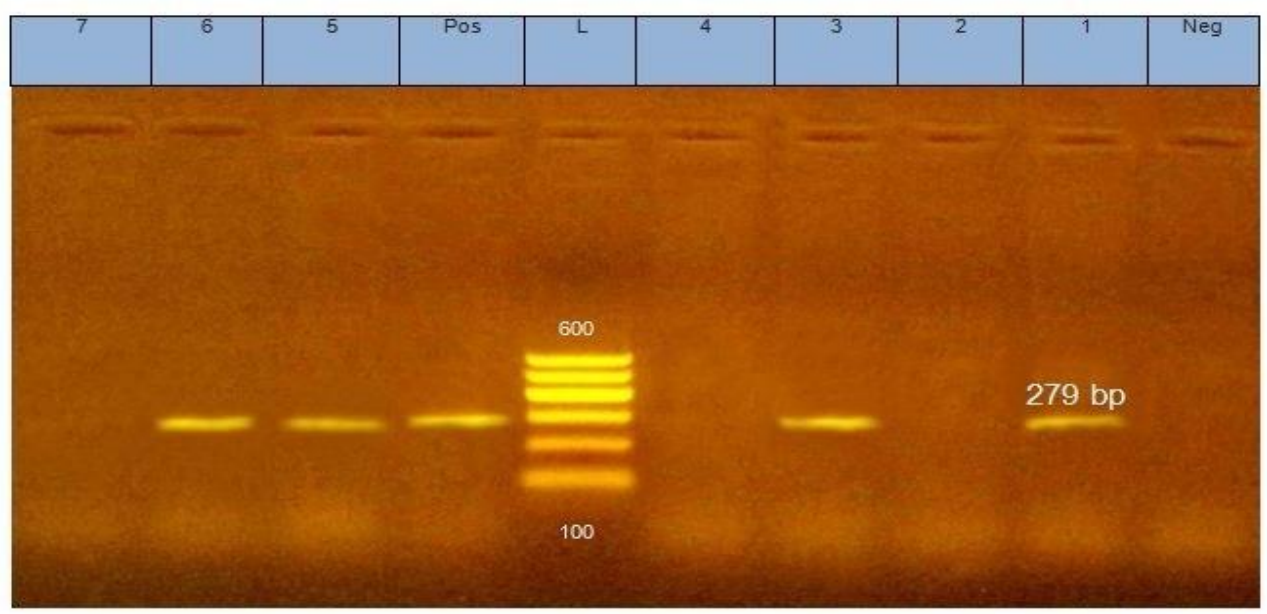

Fig .(1): Agarose gel electrophoresis of PCR for amplification products of hemeutilization protein A (chuA) gene of 7E.coli isolates. Lanes 1,3,5,6 shows positive amplification of chuA gene at 279 bp. Lane L: DNA ladder at 100-600bp. Neg.: Negative control (Staphylococcus aureus ATCC25923). Pos.: Positive control ( AJ413986 ).

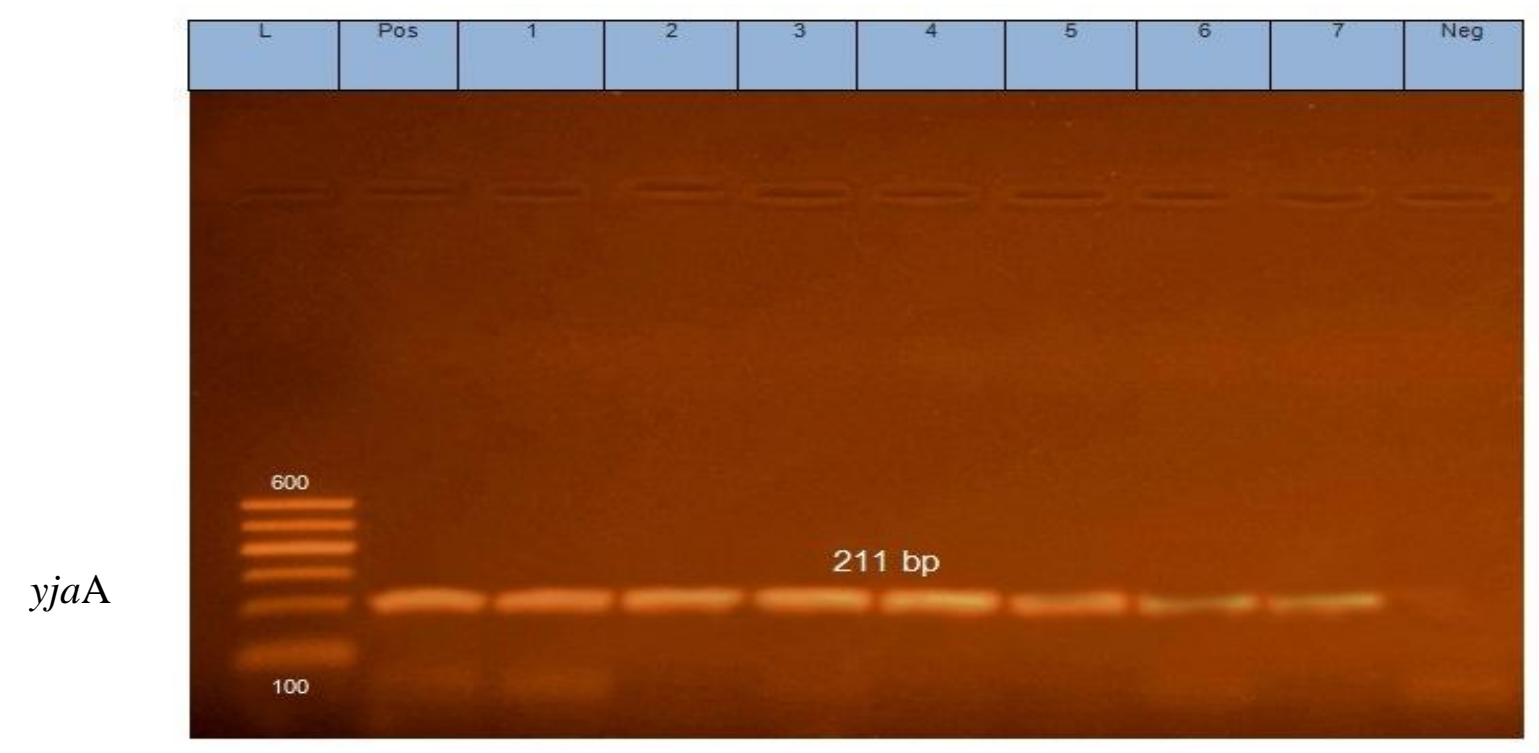

Fig. (2): Agarose gel electrophoresis of PCR for amplification products of inner membrane protien $(y j a \mathrm{~A})$ gene of 7 E.coli isolates. Lanes1,2,3,4,5,6,7 shows positive amplification of yjaA gene at 211 bp. Lane L: DNA Ladder at 100-600bp. Neg.: Negative control (Staphylococcus aureus ATCC25923). Pos.: Positive control ( AJ413986 ). 


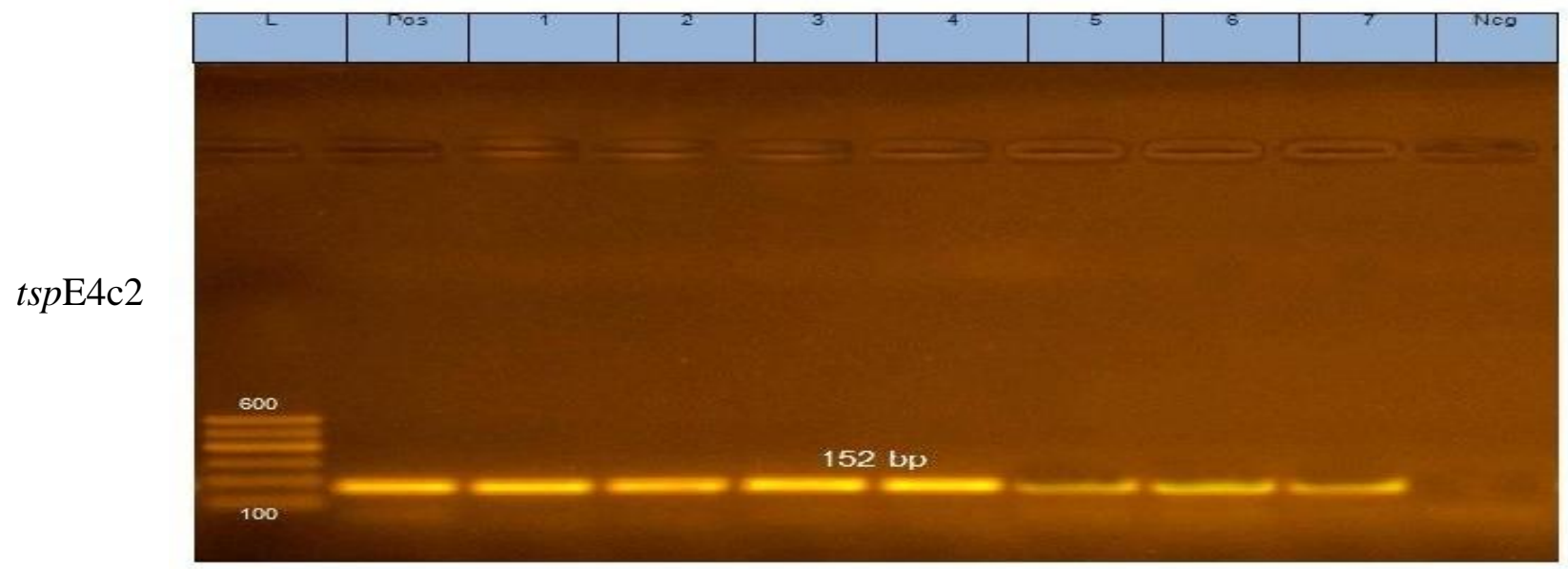

Fig. (3): Agarose gel electrophoresis of PCR for amplification products of specific DNA fragment ( $t s p \mathrm{E} 4 \mathrm{c} 2)$ gene of 7 E.coli isolates. Lanes 1,2,3,4,5,6,7 shows positive amplification of $t s p \mathrm{E} 4 \mathrm{c} 2 \mathrm{gene}$ at 152 bp. Lane L: DNA Ladder at 100-600bp.Neg.: Negative control. (Staphylococcus aureus ATCC25923). Pos.: Positive control ( AJ413986 ).

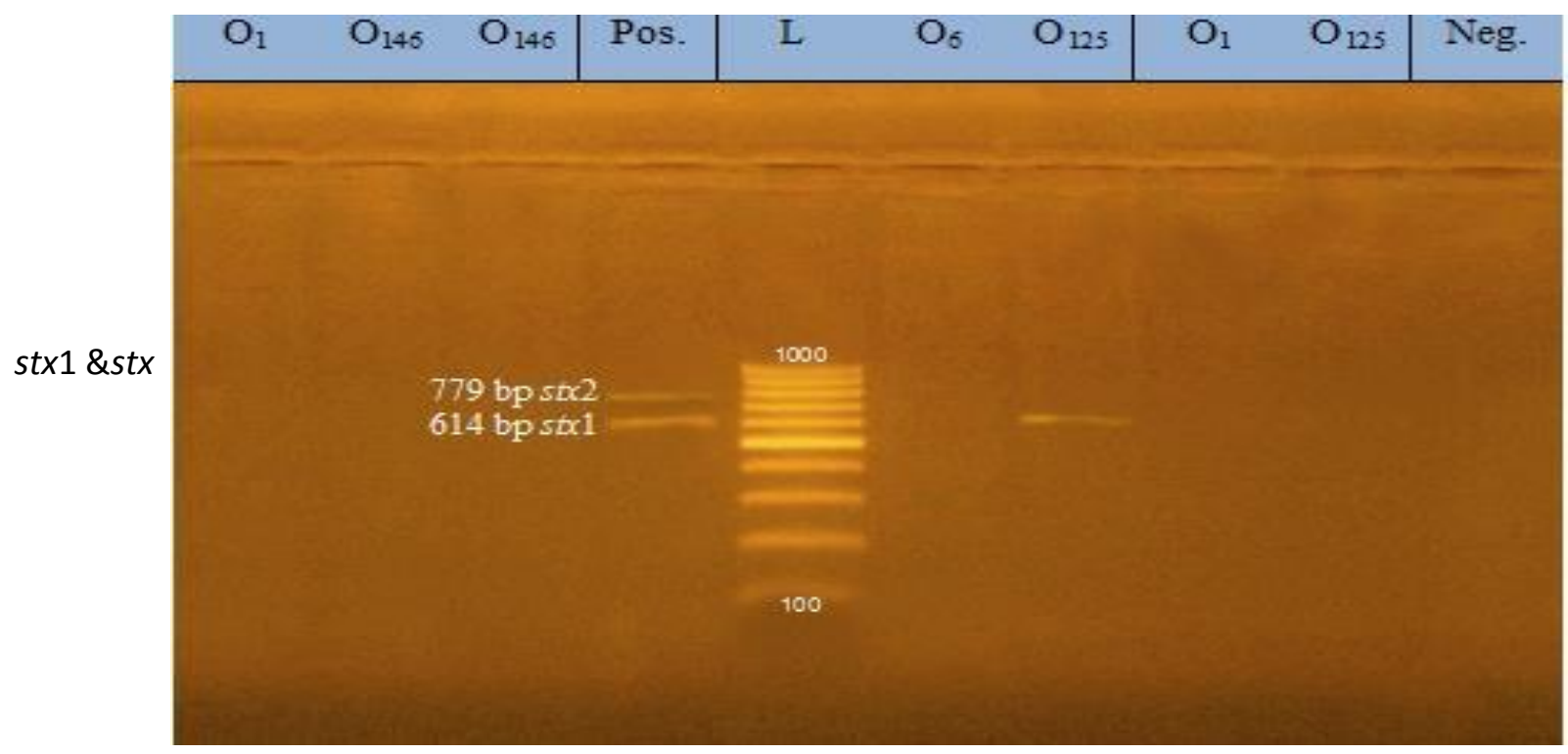

Fig.(4): Agarose gel electrophoresis of PCR for amplification products of shiga toxin $1 \& 2$ (stx1 \&stx2) genes of E. coli. Lane 3 shows positive amplification of stx 1 gene at 614 bp ,but lanes 1,2,3,4,5,6,7shows negative amplification of stx2 gene at 779 bp. Lane L: DNA Ladder at 100-1000bp. Neg.: Negative control (Staphylococcus aureus ATCC25923). Pos.: Positive control (stx1 \&stx2) (AJ413986 \& FN252457) . 


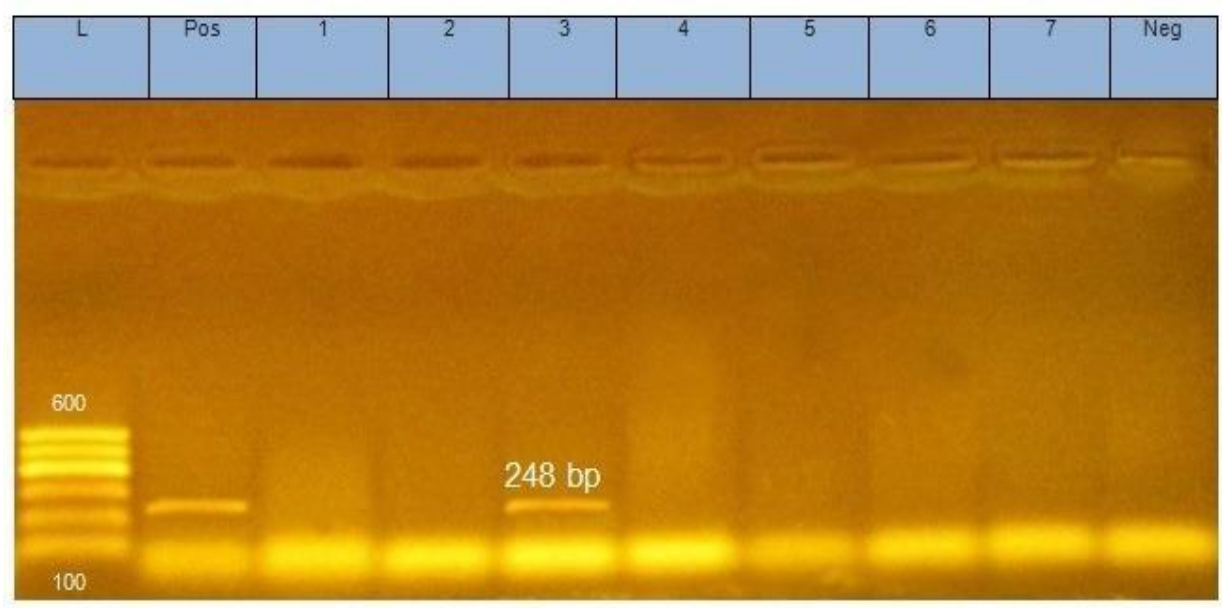

Fig.(5): Agarose gel electrophoresis of PCR for amplification products of intimin (eaeA) gene of E. coli. Lane 3 shows positive amplification of eaeA gene at 248 bp. Lane L: DNA Ladder at 100-600 bp. Neg.: Negative control (Staphylococcus aureus ATCC25923). Pos.: Positive control ( M58154).

hly \& iss

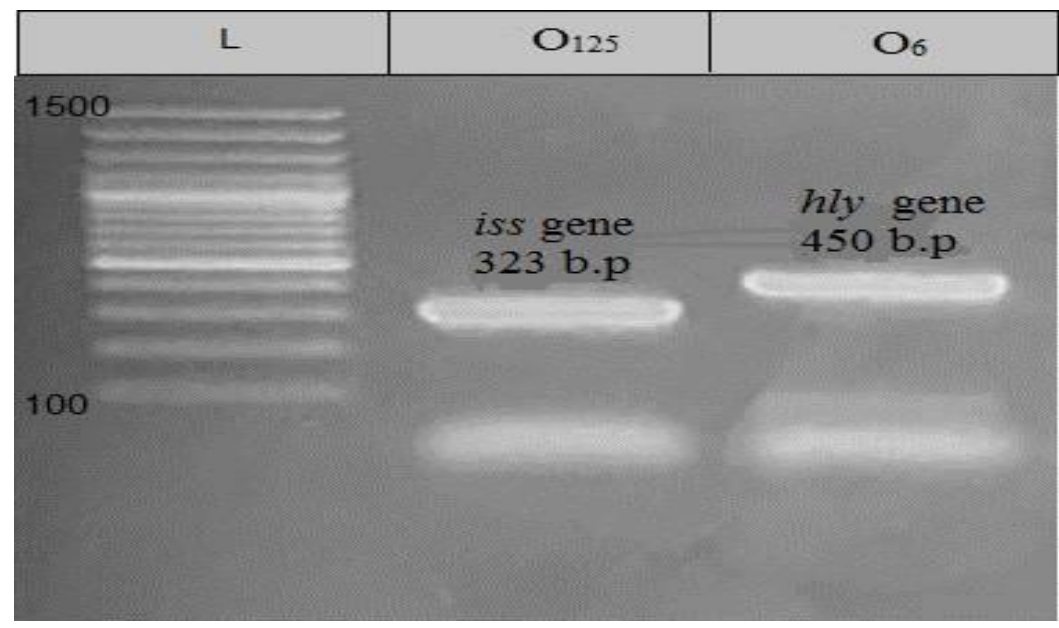

Figure (6): Agarose gel electrophoresis of of PCR for amplification products of hemolysine A (hly) and increased serum survival (iss) genes of E.coli. Lane 3 shows positive amplification of hly gene at $450 \mathrm{bp}$ and lane 2 shows positive amplification of iss gene at $323 \mathrm{bp}$.Lane L: DNA Ladder at 100-1500bp. Neg.: Negative control (Staphylococcus aureus ATCC25923). Pos.: Positive control ( hly \& iss ) ( NG036728.1 \& DQ309287). 


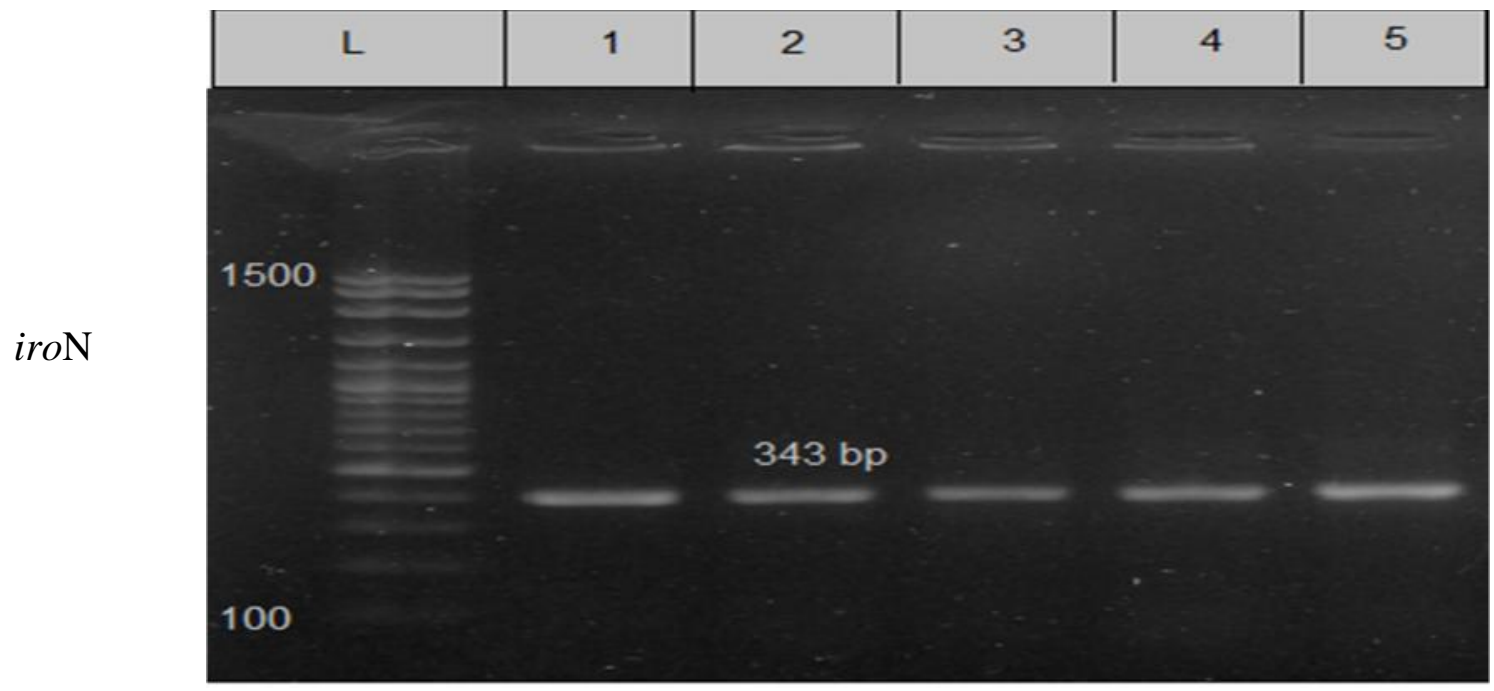

Fig. (7): Agarose gel electrophoresis of PCR for amplification products of iroN gene of K.oxytoca. Lanes1,2,3 shows negative amplification of iroN gene at 847 bp .Lane L: DNA Ladder at 100-1000 bp. Pos.: Positive control (ATCCr13182) .

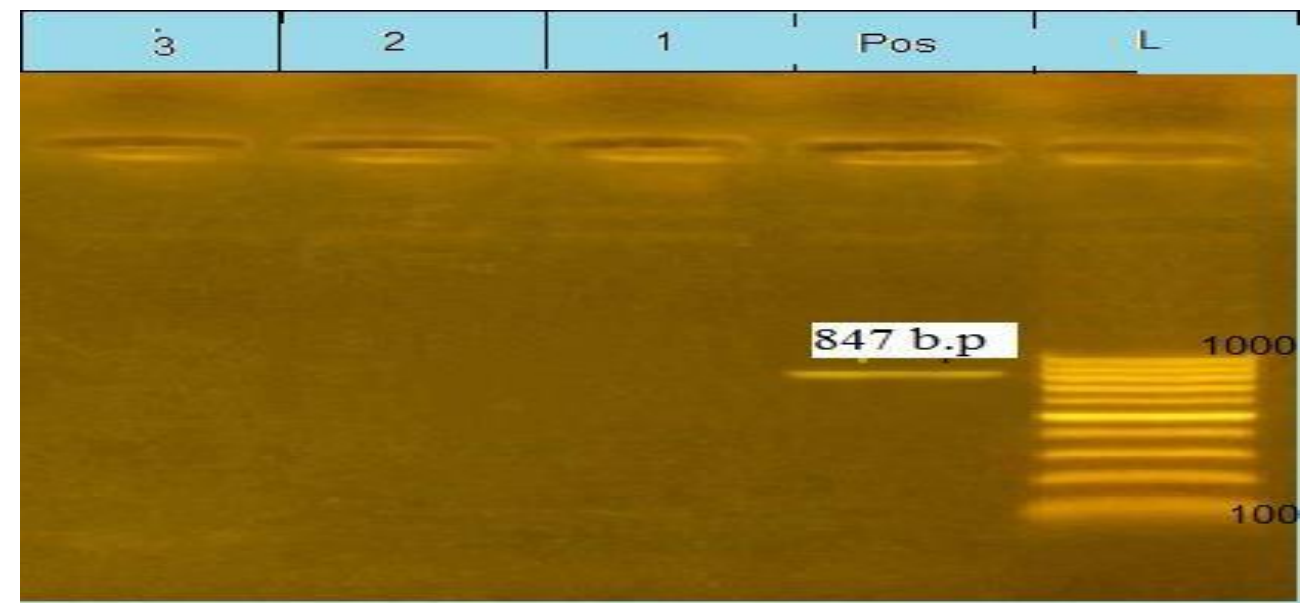

Fig.(8): Agarose gel electrophoresis of PCR for amplification products of Poly galacturonase gene (pehX) of $K$. oxytoca. Lanes1,2,3,4,5 shows positive amplification of pehX gene at 343bp.Lane L: DNA Ladder at100- 1500 bp.

\section{DISCUSSION}

Poultry represent an important source of meat, eggs and edible offals. Many bacterial agents were found to affect the raising of chickens. The present results revealed many bacterial agents isolated from visceral organs of diseased chickens representing different ages and sexes. Ten bacterial species isolated were $E$. coli (53), $K$. oxytoca (5), S.spp (31), Citrobacter freundii (14), Enterobacter cloacae (6), Enterobacter 
gergoviae (2), Enterobacter pantoe (2), Acinetobacter lowoffii (4), Proteus vulgaris (4), Edwardsiella tarda (4).

All samples collected indicated the unhygienic environment of the farm included feed, water, poor ventilation, wild animals and insects. Also contaminated hatchery and workers have a main role in infection or cross infection even its spread. The present infection resulted from horizontal infection through direct or indirect contact with other infected bird - cannibalism - or ingestion of infected feed ( especially $\boldsymbol{E}$. coli) or water with excreta or misusing of live vaccines ( especially Sallmonella species). Vertical transmission also occur through egg infection by fecal contamination of the egg surface with subsequent penetration of the shell and membranes .Moreover excessive and indiscriminate use of antimicrobials led to presence of strains highly resistant to most of them. Escherichia coli isolates were 53 isolates as in studies of Makhol et al.,(2010), Abd El Tawab et al.,(2016) and Halfaoui et al.,(2017). In spite of Abbott et al.,(2003), Hyma et al.,(2005)and Oaks et al.,(2010) isolated E.alberti, and Poulou et al.,(2008), Yamanaka et al.,(2010) isolated E. hermannii , and E. vulneris was found by Mohanty et al.,(2005) and Kilani et al.,(2008) and they were absent the isolates .

Salmonella species isolates were 31 isolates and agreed with Ammar et al.,(2016) , Zhao et al., (2016) and Abd El Tawab et al.,(2017).

Five isolates of K.oxytoca were found as reported in Brisse et al.,(2006) and Jiang et al.,(2014). Despite of isolation of $K$. pneumonia from Keynan and Rubinstein (2007), Zadoks et al.,(2011) and Siu et al.,(2012) and $K$. granulomatis from Lagergard et al.,(2011) and this results were free of them . Fourteen Citrobacter freundii isolates were recovered although Borenshtein and Schauer (2006) isolated Citrobacter spp. and VazMarecos et al.,(2012) isolated $C$. koseri (diversus).

Enterobacter pantoe was 2 isolates as well as Enterobacter gergoviae, but Enterobacter cloacae was 6 isolates which agreed with Mezzatesta et al.,(2012). Al-Hasan et al.,(2011) isolated Enterobacter spp. Four isolates were recovered of Acinetobacter lowoffii, Proteus vulgaris and Edwardsiella tarda. These isolates do not reflect the picture of the disease as reflect the health and immune state of the bird. Also all isolated microorganisms are commensal bacteria which co-evolved with their hosts in gastrointestinal track especially the lower parts however, under specific conditions, they overcome protective host responses and exert pathologic effects.

E. coli represented the most common isolated bacteria from all samples that recovered from all tested organs. It was resistant to almost antimicrobial agents used except amikacin, gentamicin and apramycin as Makhol et al.,(2010) and Zhang et al.,(2012). When examined some E. coli isolates, found that there are extra-intestinal pathogenic E. coli as mentioned in Köhler and Dobrindt (2011) and Comery et al.,(2013). The strain of $E$. coli serovared $\mathrm{O}_{1}$ agreed with Younis et al.,(2017) and Han et al.,(2018), that serovared $\mathrm{O}_{2}$ agreed with Salama et al., (2007) and Halfaoui et al.,(2017) , that serovared $\mathrm{O}_{125}$ agreed with Abd El Tawab et al.,(2016) and Ozaki et al.,(2017) and that serovared $\mathrm{O}_{146}$ agreed with Sánchez et al.,(2015) and Mughini-Gras et al., (2018). All results indicated that E.coli strains isolated were extra-intestinal pathogenic strains (Morales et al., 2004, Smith, et al., 2007 , Mellata 2013and Delannoy et al., 2017). 
Genotypic characterization of tested E.coli revealed absence of stx 1 in all isolates, but Fierz et al.,(2017) found it, presence of st 2 , eae A and hly genes in one sample as mentioned in Momtaz and Jamshidi (2013), $\underline{\text { Alonso }}$ et al.,(2017) and Friesema et al.,(2014) and iss gene in another one as detected in Abd El Tawab et al.,(2014) and Johnson et al.,(2008).

$K$. oxytoca represented 5 isolates that recovered from all tested organs. It was resistant to almost antimicrobial agents used except amikacin, gentamicin and oxytetracycline as recorded in $\mathrm{Wu}$ et al.,(2016). All tested isolates had pehX gene that misidentified in other Klebsiella species which was agreed with Kovtunovych et al.,(2003) and Zedan et al., (2017). Antimicrobial sensitivity test to the other isolates showed marked fluctuation to many antimicrobial agents used due to the misuse of these chemotherapeutics in the routine raising of chickens which affect the bird immunity and body gain.

It is a wrong concept of using antimicrobial agents for growth promotion in animals. The overuse and misuse of these chemotherapeutics to chickens not only affect on them, but also affect on all human beings and animals. We should limit its use only to sick bird to eliminate chemotherapeutics from human food chain.

$\mathrm{O}_{125}$ and 146 are human specific E. coli and this indicate human ceacal infection by workers through bad hygiene and habits.

\section{REFERENCES}

Abbott, S. L.; O'Connor, J.; Robin, T.; Zimmer, B.L. and Janda, J,M .(2003) : Biochemical properties of a newly described Escherichia species, Escherichia albertii. J. Clin. Microbiol. , 41:4852-4854 .
Abd EL-Tawab, A. A.; Ammar, A. M. A.; Hamouda, A. M. A.; El-Hofy, F. I. A. and El gamal, A. A. A. (2016): Synergistic antimicrobial activity of black pepper extract with some antibiotics combination on Escherichia coli isolated from chickens , B.V.M.J., 32(1): 1-6.

Abd EL-Tawab, A. A.; Ammar, A. M. A.; El-Hofy, F. I. A.; Abd el-Hakeem, M. and Abdel Galil, N. M. (2016): Molecular Screening Of Virulence Genes In Avian Pathogenic Esherichia Coli , B.V.M.J., 30(1) 137-149.

Abd El Tawab, A. A.; Hamouda, N. S. and Dowidar, S. M. (2017) : Molecular Studies on Antimicrobial Resistance Genes in Multiple drug resistant Salmonella Serovares and Staphylococcus aureus isolated from Chickens , B.V.M.J.

Abd El Tawab, A. A.; Maarouf, A. A. A.; Abd El Al, S. A.; El Hofy, F. I. and El Mougy, E. E. A. (2014 ):Detection of some virulence genes of avian pathogenic E. Coli by polymerase chain reaction, B.V.M.J., 26 (1): 159-176 .

Al-Hasan, M. N.; Lahr, B. D.; EckelPassow, J. E. and Baddour, L.M. (2011) : Temporal trends in Enterobacterspecies bloodstream infection : a population-based study from 1998-2007.Clin.Microbiol. Infect. 17:539-545.

Alonso, C. A.; Mora, A.; Díaz, D.; Blanco, M.; González-Barrio, D. ; Ruiz-Fons, F.; Simón, C.; Blanco, J. and Torres, C. (2017) :Occurrence and characterization of stx and/or eaepositive Escherichia coli isolated from wildlife, including a typical EPEC strain from a wild boar. Vet. Microbiol. ; 207: 69-73. 
Ammar, A. M.; Mohamed, A. A.; Abd ElHamid , M.I. and El-Azzouny, M. M. (2016 ) : Virulence genotypes of clinical Salmonella Serovars from broilers in Egypt. J. Infect. Dev. ; 10 (4) : 337-46.

Bisi-Johnson, M. A.; Obi, C. L.; Vasaikar, S. D.; Baba, K. A. and Hattori, T. (2011): Molecular basis of virulence in clinical isolates of Escherichiacoli andSalmonella species from a tertiary hospital in the Eastern Cape, South Africa. Gut. Pathogens, 3:9.

Borenshtein, D. and Schauer, D. B (2006) :The genus Citrobacter.In:Dworkin M, Falkow S, Rosenberg E, Schleifer KH, Stackebrandt E (eds) The prokaryotes :proteobacteria: gamma subclass, Springer, New York,( 6) 9098 .

Brisse, S.; Grimont, F. and Grimont, P. A. D. (2006) : The genusKlebsiella. In: Dworkin M, Falkow S, Rosenberg E, Schleifer KH, Stackebrandt E (eds) The prokaryotes: proteobacteria: gamma subclass, Springer, New York, (6) 159-196 .

Chander, Y.; Ramakrishnan, M.A.; Jindal, N.; Hanson, K. and Goyal, S.M. (2011): Differentiation of Klebsiella pneumoniae and $K$. oxytoca by Multiplex Polymerase Chain Reaction. Int. J. Appl. Res. Vet. Med. 9 (2): 138-142.

Clinical and Laboratory Standards Institute (CLSI), 2008: performance standards for antimicrobial disk and dilution susceptibility tests for bacteria isolated from animals, third ed. approved standard m31a3.clinical and laboratory standards institute, wayne, pa, USA.

Clinical and Laboratory Standards Institute (CLSI), 2017: Performance standards for antimicrobial susceptibility tests; approved standard, eleventh ed (M27).

Comery, R.; Thanabalasuriar, A.; Garneau, P.; Portt, A.; Boerlin, P.; Reid-Smith, R. J.; Harel, J.; Manges, A. R. and Gruenheid, S. (2013) :Identification of potentially diarrheagenic atypical enteropathogenic Escherichia coli strains present in Canadian food animals at slaughter and in retail meats. Appl. Environ. Microbiol.; 79(12) : 38923896.

Dipineto, L.;Santaniello,
A.; Fontanella,
M.; Lagos,
K.; Fioretti, A. and Menna, L. F.(2006) : Presence of Shiga toxin- producing Escherichia coli O157:H7 in living layer hens . Lett. Appl. Microbiol., 43(3) : 293-295.

Delannoy, S.; Beutin, L.; MarianiKurkdjian, P.; Fleiss, A.; Bonacorsi, S. and Fach, P. (2017) : The Escherichia coli serogroup $\mathrm{O}_{1}$ and $\mathrm{O}_{2}$ lipopolysaccharides are encoded by multiple O-antigen gene clusters. Front Cell Infect. Microbiol., 7: 30.

Ewers, C.; Li, G.; Wilking, H.; Kiebling, S.; Alt, K.; Antáo, E.M.; Laturnus, C.; Diehl, I.; Glodde, S.; Homeier, T.; Böhnke, U.; Steinrück, H.; Philipp, H.C. and Wieler, L.H. (2007):Avian pathogenic, uropathogenic, and newborn meningitis-causing Escherichia coli: How closely related are they? 
International Journal of Medical Microbiology, 297 163-176.

Fairbrother, J. M.; Nadeau, E. and Gyles, C.L. (2005) :Escherichia coli in post weaning diarrhea in pigs: an update on bacterial types, pathogenesis, and prevention strategies . Animal Health Research Revue, (6)17-39.

Fierz, L.; Cernela, N.; Hauser, E.; Nüesch-Inderbinen,

M.andStephan, R. (2017 ) : Characteristics of Shiga toxin Producing Escherichia coli Strains isolated during 2010-2014 from Human Infections in Switzerland. Front. Microbiol., 8:1471.

Friesema, I.; van der Zwaluw, K.;Schuurman, T.; Kooistra-Smid, M.;Franz, E. ; vanDuynhoven, Y. and van Pelt, W. (2014) : Emergence of Escherichia coli encoding Shiga toxin $2 \mathrm{f}$ in human Shiga toxin-producing E. coli (STEC) infections in the Netherlands, Euro. Surveill., 19 (17) ; 26-32.

Halfaoui, Z,; Menoueri, N. M. and Bendali, L. M. (2017): Serogrouping and antibiotic resistance of Escherichia coli isolated from broiler chicken with colibacillosis in center of Algeria. Vet. World, (7): 830-835.

Han,Y.; Liu, Q.; Willias, S,; Liang, K.; Li, P.; Cheng, A. andKong, Q. (2018) : A bivalent vaccine derived from attenuated Salmonella expressing O-antigen polysaccharide provides protection against avian pathogenic Escherichia coli $\mathrm{O}_{1}$ and
$\mathrm{O}_{2} \quad$ infection. $\quad$ Vaccine. $; 36$ (8):1038-1046.

Hyma, K. E.; Lacher, D. W.; Nelson, A. M.; Bumbaugh, A. C.; Janda, J. M.; Strockbine, N. A.; Young, V. B. and Whittam, T. S. (2005) : Evolutionary genetics of a new pathogenic Escherichia species: Escherichia albertii and related Shigella boydii strains. J. Bacteriol., 187: 619-628 .

Jiang, J.; Min Tun, H.; Mauroo, N. F.; Po Yee Ma, A.; Yuen Chan, S. and Leung, F. C. (2014) : Complete genome sequence and comparative genome analysis of Klebsiella oxytoca HKOPL1 isolated from giant panda feces. BMC Research Notes, $7: 827$.

Jeong, Y.W.; Kim T.E.; Kim, J.H.andKwon, H.J. (2012):Pathotyping avian pathogenic Escherichia coli strains in Korea. J. Vet. Sci., 13(2) :145-52.

Johnson, R. J.; Johnston, B.; Clabots, R. C.; Kuskowski, M.; Roberts, E. and DebRoy, C. ( 2008) :Virulence genotypes and phylogenetic background of Escherichia Coli serogroup $\mathrm{O}_{6}$ isolates from humans, dogs, and cats. Journal of clinical microbiology, 46(2) 417-422.

Johnson, T. J.; Wannemuehler, Y. M. and Nolan, L. K. (2008) : Evolution of the iss gene in Escherichia coli. Appl. Environ. Microbiol.,74(8): 2360-2369.

Keynan, Y. and Rubinstein, E. (2007): The changing face of Klebsiella pneumonia infections in the community. Int. J. Antimicrob. Agents, 30:385-389 . 
Kilani, B.; Ammari, L.; Benaissa, H. T.; Ben Chaabane, T. and Fendri, C. (2008): Escherichia vulneris as a cause of bacteremia in a patient with chronic lymphocytic leukemia. Int. J. Infect. Dis.,12 : 110-111.

Kisiela, D. I.; Chattopadhyay, S.; Libby, S. J.; Karlinsey, J. E.; Fang, F. C.; Tchesnokova, V.; Kramer, J. J.; Beskhlebnaya, V.; Samadpour, M.; Grzymajlo, K.; Ugorski, M.; Lankau, E. W.; Mackie, R. I.; Clegg, S. and Sokurenko, E. V. (2012) : Evolution of Salmonella enteric virulence via point mutations in the fimbrial adhesin. PLOS Pathog., 8:e1002733.

Köhler, C. D. and Dobrindt, U. (2011) :What defines extra-intestinal pathogenic Escherichia coli? International Journal of Medical Microbiology, 301, 642-647.

Kovtunovych, $\quad$ G.; Lytvynenko, T.; Negrutska, V.; Lar, O.; Brisse, S. andKozyrovska, N. ( 2003) :Identification of Klebsiella oxytoca using a specific PCR assay targeting the polygalacturonasepehX gene. Res. Microbiol.;154 (8) :587-592 .

Lagergard, T.; Bolin, I. and Lindholm, L. (2011) : On the evolution of the sexually transmitted bacteria Haemophilus ducreyi and Klebsiella granulomatis. Ann. N. Y. Acad. Sci. 1230: E1-E10.

Makhol, B. M.; Habreh, N. And Sakurai, K. (2010):Antibiotic resistance of Escherichia Coli isolated from poultry in Syria .Assiut.veterinary medical journal .

Markey, $\quad$ B.; $\quad$ Leonard, F.; Archambault, M.; Cullinane, A. and Maguire, D. (2013): Clinical veterinary microbiology second Ed. MOSBYELSEVIER Chapter 3: 49-58 , Chapter $6: 79-102$, Chapter $17: 239-274$.

Mellata, M. (2013) :Human and avian extra-intestinal pathogenic Escherichia coli: infections, zoonotic risks, and antibiotic resistance trends. Foodborne Pathog. Dis., 10 (11):916932.

Mezzatesta, M. L.; Gona, F. and Stefani, S. (2012) : Enterobacter cloacae-complex: clinicalimpact and emerging antibiotic resistance. Future Microbiol., 7:887-902.

Microgen GnA+ B- ID system: An identification system for currently recognized Enterobacteriaceae and an extensive range of oxidase- positive gram negative bacilli. WWW.Microgen Bioproducts.com.

Mohanty, S.; Chandra, S. P.; Dhawan, B.; Kapil, A. and Das, B. K. (2005): Meningitis due to Escherichia vulneris. Neurol. India 53:122-123.

Momtaz, H. and Jamshidi,A. (2013) :Shiga toxin-producing Escherichia coli isolated from chicken meat in Iran : Serogroups, virulence factors, and antimicrobial resistance properties . Poultry Science 92 : $1305-1313$.

Morales, C.; Lee, M. D.; Hofacre, C. and Maurer, J. J.(2004) : Detection of a novel virulence gene and a Salmonella virulence homologue among Escherichia coli isolated from broiler chickens. Foodborne Pathog. Dis. Fall., 1(3):160-165. 
Mughini-Gras, L.; van Pelt, W.; van der Voort, M.; Heck, M.; Friesema, I. and Franz, E. (2018) : Attribution of human infections with Shiga toxinproducing Escherichia coli (STEC) to livestock sources and identification of source-specific risk factors, The Netherlands (20102014). Zoonoses Public Health, 65(1):e8-e22.

Nagy, B. and Fekete, P. Z. ( 2005) : Enterotoxigenic Escherichia Coli in veterinary medicine. International Journal of Medicinal Microbiology, $295 ; 443-454$.

Oaks, J. L.; Besser, T. E.; Walk, S. T.; Gordon, D. M.; Beckmen, K. B.; Burek, K. A.; Haldorson, G. J.; Bradway, D. S.; Ouellette, L.; Rurangirwa, F. R.; Davis, M. A.; Dobbin, G. and Whittam, T. S. (2010) :Escherichia albertii in wild and domestic birds. Emerg. Infect. Dis., 16: 638-646.

Ozaki, H.; Matsuoka, Y.; Nakagawa, E.and Murase, T. (2017) : Characteristics of Escherichia coli isolated from broiler chickens with colibacillosis in commercial farms from a common hatchery. Poult. Sci., 1; 96(10):3717-3724.

Poulou, A.; Dimitroulia, E.; Markou, F. and Tsakris, A. (2008) :Escherichia hermanniias the sole isolate from a patient with purulent conjunctivitis. J. Clin. Microbiol., 46 : 3848-3849.

Salama S. S.; Kheder, A. A.; Elebiary, E. A. and Taha, M. M. (2007):Molecular strategies for the differentiation and identification of local E. coli isolated from chicken: I. Characterization of protein profile. Bs. Vet. Med. J., $17(1) ; 25-28$.

Sambrook, J.; Fritscgh, E.F. and Maniates, T. (1989): Molecular coloning. A laboratory manual.Vol !., Cold spring Harbor Laboratotry press, New York.

Sánchez, S.; Llorente, M. T.; Echeita, M. A. andHerrera-León, S. (2015) : Development of three multiplex PCR assays targeting the 21 most clinically relevant serogroups associated with Shiga toxinproducing E. coli infection in humans . PLoS One. 10 (1) : e0117660 .

Siu, L. K.; Yeh, K. M.; Lin, J. C.; Fung, C. P. and Chang, F. Y. (2012) :Klebsiella pneumonia liver abscess: a new invasive syndrome. Lancet. Infect. Dis., 12:881-887.

Smith, J. L.; Fratamico, P. M.and Gunther, N. W(2007): Extra-intestinal pathogenic Escherichia coli. Foodborne Pathog. Dis., 4(2):134-163.

VazMarecos, C.; Ferreira, M.; Ferreira, M. M.; Barroso, M. R. (2012): Sepsis, meningitis and cerebral abscesses caused by Citrobacter koseri. B. M. J. Case Rep., 1020114941.

WHO (2002): World Health organization. Department of communicable diseases surveillance and response.

Wu, H.; Wang, M.; Liu, Y.; Wang, X.; Wang, Y.; Lu. J. andXu, H. (2016) : Characterization of antimicrobial resistance in Klebsiella species isolated from chicken broilers.Int. J. Food Microbiol., 232; 95-102. 
Yamanaka, T.; Sumita-Sasazaki, Y.;

Sugimori, C.; Matsumoto-

Mashimo, C.; Yamane, $\mathrm{K}$.; Mizukawa, K.; Yoshida, M.; Hayashi, H.; Nambu, T.; Leung, K. P. and Fukushima, H. (2010) : Biofilm-like structures and pathogenicity of Escherichia hermannii YS-11, a clinical isolate from a persistent apical periodontitis lesion. FEMS Immunol. Med. Microbiol., 59: 456-465.

Yegani, M. and Korver, D. R. (2008): Factors affecting intestinal health in poultry. Poult. Sci. 87:20522063 .

Younis, G.; Awad, A. and Mohamed, N.(2017): Phenotypic and genotypic characterization of antimicrobial susceptibility of avian pathogenic Escherichia coli isolated from broiler chickens. Veterinary World, (10): 1167-1172.

Yue, M.; Rankin, S. C.; Blanchet, R. T.; Nulton, J. D.; Edwards,R. A. and Schifferli, D. M. (2012): Diversification of the Salmonella fimbriae : a model of macro and micro-evolution. PLoS. One 7 : e 38596.

Zadoks, R. N.; Middleton, J. R.; McDougall, S.; Katholm, J. and Schukken, Y. H. (2011) : Molecular epidemiology of mastitis pathogens of dairy cattle and comparative relevance to humans. J. Mammary Gland Biol. Neoplasia. 16: 357-372.

Zedan, T. H. (2017): Molecular Discrimination of Klebsiella oxytoca using Polymerase Chain Reaction Targeted Polygalacturonase (pehX) gene. International journal of current microbiology and applied sciences, 6 (6) : 2092-2098.

Zhang, T.; Wang, C. G. and Zhong, X. H.(2012):Survey on sulfonamide antibiotic-resistant genotype and phenotype of avian Escherichia coli in North China. Poult.Sci.,91(4):884887.

Zhao, X.; Gao, Y.; Ye, C.; Yang, L.; Wang, T. and Chang, W.( 2016) : Prevalence and Characteristics of Salmonella Isolated from Free-Range Chickens in Shandong Province, China. Biomed. Res. Int.8183931. 